Many Times, But Then 
University of Texas Press Poetry Series, NO. 4 
Many Times, But Then

\author{
By Ann Lauterbach
}

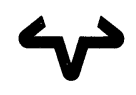

University of Texas Press, Austin and London 
Lauterbach, Ann, I942Many times, but then.

(The University of Texas Press poetry series; no. 4)

I. Title.

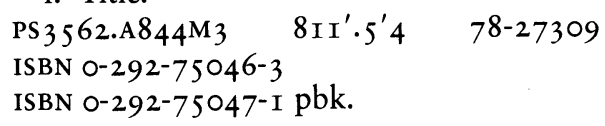

Copyright (C) 1979 by Ann Lauterbach All rights reserved

Printed in the United States of America

Permission to publish the following poems is gratefully acknowledged:

"Romance," Partisan Review 45, no. I: IO. Copyright (C) 1978 by Partisan Review, Inc.

"A Visit to the Country," Partisan Review 43, no. 3: 407. Copyright (C) 1976 by Partisan Review, Inc.

"Gramercy Park Evening," "True and False Green," "After All," "Connie's Window, Nantucket," Roof 2 (Spring I 977).

"Chalk," ZZZ, ed. Kenward 'Elmslie, copyright (C) I 974 by Z Press, and "Last Night it Rained," "January Hill," "Parabolas of Spring," ZZZZZZ, ed. Kenward Elmslie, copyright (c) 1977 by $Z$ Press.

"September Solitaire," Heresies 2 (May I977), p. 47.

"Single File," "Between," "The Day After," Là Bas i I (March I978).

"Second Descent: I 975," "True and False Green," "Alternating Articles," "Tremors in a Late Age," "Chappaqua Reverie," "Words to Assuage,” Book One, ed. Sal Incontro, copyright (C) I 975 by the Spring Street Press.

"Many Times, But Then," "Reynolda Gardens," "Along the Way," Poetry in Motion, no. I I, ed. David Lehman, I979.

"Poem," "Quotations from Reality," The Little Magazine I I, no. I (Spring 1977).

"Then Suddenly," The Face of the Poet, by Alex Katz. New York: Brooke Alexander, Inc., I979.

"The White Sequence," "Configuration of One," The Little Magazine ı, no. 2 (Summer I976).

“Gray Morning," The New York Arts Journal, no. 8 (February and March I 978).

"Window," The Nation, April 2, I 977.

"Winter Sky," "East River Barge," The Poetry Mailing List, ed. and pub. Steven Paul Miller, New York, I 977.

"These," "Stories without Endings," Grey Art Gallery, New York University, New York, I979.

"The Relinquished," Stooge 7 (May I 972).

"The Green Scarf," Jazz4/Linguis (April I979).

"Gardenia," The Poetry Project Newsletter, no. 62 (February I 979). 


\section{for Priscilla}

\section{and for Tom Prideaux}

Ought not these oldest sufferings of ours to be yielding more fruit by now? Is it not time that, in loving, we freed ourselves from the loved one, and, quivering, endured:

as the arrow endures the string, to become, in the gathering out-leap, something more than itself? For staying is nowhere.

Rilke, First Elegy 
THIS PAGE INTENTIONALLY LEFT BLANK 